\title{
PERBANDINGAN MODEL PEMBELAJARAN KOPERATIF TIPE CIRC DAN TTW PADA AKTIVITAS BELAJAR MAHASISWA
}

\author{
Ani Interdiana Candra Sari ${ }^{1}$, Rendika Vhalery ${ }^{1}$ \\ Pendidikan Ekonomi Universitas Indraprasta PGRI Jakarta ${ }^{1,2}$ \\ Email: incasani26@gmail.com
}

\begin{abstract}
ABSTRAK
Aktivitas belajar merupakan faktor penting dalam proses pembelajaran yang dapat mencerminkan adanya motivasi ataupun keinginan mahasiswa untuk belajar. Namun, pada pelaksanaannya tidak berjalan dengan lancar. Ketidaklancaran ini disebabkan oleh permasalahan seperti mahasiswa lebih banyak duduk diam dan mendengarkan penjelasan dosen. Hal ini dapat menimbulkan dampak negatif, dimana mahasiswa akan menjadi pasif. Penerapan model pembelajaran yang tepat, merupakan salah satu strategi dalam pembelajaran untuk meningkatkan aktivitas belajar mahasiswa. Salah satu model pembelajaran yang dapat digunakan untuk meningkatkan aktivitas belajar adalah model pembelajaran kooperatif. Ada banyak tipe model pembelajaran kooperatif diantaranya CIRC (Cooperative Integrated Reading Composition) dan TTW (Think-Talk-Write). Penelitian ini adalah penelitian eksperimen yang menggunakan Completely Randomized Design yang tidak menggunakan kelas kontrol. Lalu dilanjutkan dengan penelitian komparatif yang membandingkan model pembelajaran kooperatif tipe CIRC dan TTW pada aktivitas belajar mahasiswa. Kelas eksperimen 1 menggunakan model pembelajaran kooperatif tipe CIRC dan kelas eksperimen 2 menggunakan model pembelajaran kooperatif tipe TTW. Hasil penelitian menunjukkan bahwa tidak ada perbedaan rata-rata aktivitas belajar mahasiswa dengan menggunakan model pembelajaran kooperatif tipe CIRC, ada perbedaan rata-rata aktivitas belajar mahasiswa dengan menggunakan model pembelajaran kooperatif tipe TTW, tidak ada perbedaan dalam menggunakan model pembelajaran kooperatif tipe CIRC dan TTW pada aktivitas belajar mahasiswa.
\end{abstract}

Kata Kunci : CIRC, TTW, Aktivitas Belajar, Model Pembelajaran

\begin{abstract}
Learning activity is an important factor in the learning process that can reflect the motivation or desire of students to learn. However, the implementation does not go well. It is caused by problems such as students sitting more still and listening to lecturers' explanations. It will give a negative impact where students will become passive. The application of an appropriate learning model is one of the strategies in learning to increase student learning activities. One of the learning models that can be applied to improve learning activities is the cooperative learning model. There are many types of cooperative learning models including CIRC (Cooperative Integrated Reading Composition) and TTW (Think-TalkWrite). This research was an experimental study using a Completely Randomized Design that did not use a control class. Then it proceeded with comparative research that compared the cooperative learning models CIRC and TTW on student learning activities. Experimental class 1 applied the CIRC cooperative learning model and experimental class 2 applied the TTW cooperative learning model. The results showed that there was no difference in the average learning activity of students using the CIRC type of cooperative learning model, there was a difference in the average learning activity of students using the TTW type of cooperative learning model, there was no difference in using the CIRC and TTW cooperative learning models on student learning activities.
\end{abstract}

Keywords: CIRC, TTW, Learning Activities, Learning Models

\section{PENDAHULUAN}

Aktivitas belajar mahasiswa merupakan faktor penting dalam proses pembelajaran [1]. Aktivitas mahasiswa selama pembelajaran mencerminkan adanya motivasi ataupun keinginan mahasiswa untuk belajar [2]. Menurut [3], aktivitas belajar mahasiswa dituntut aktif mengikuti proses pembelajaran yang dapat dilihat dari kesungguhan memperhatikan penjelasan dosen, mengajukan pertanyaan terhadap hal-hal yang kurang dipahaminya ataupun 
ketekunannya dalam mengerjakan tugas yang diberikan oleh dosen. Namun, pada pelaksanaannya tidak berjalan dengan lancar. Ketidaklancaran ini disebabkan oleh permasalahan seperti mahasiswa lebih banyak duduk diam dan mendengarkan penjelasan dosen. Hal ini dapat menimbulkan dampak negatif, dimana mahasiswa akan menjadi pasif seperti mengantuk, malas, tidak mendengarkan, dan bahkan dapat menurunkan daya berpikir mereka [4].

Penerapan model pembelajaran yang tepat, merupakan salah-satu strategi dalam pembelajaran untuk meningkatkan aktivitas belajar mahasiswa [5]. Pemilihan model pembelajaran yang sesuai dengan tujuan kurikulum dan potensi siswa merupakan kemampuan dan keterampilan dasar yang harus dimiliki oleh seorang guru [6]. Salah satu model pembelajaran yang dapat digunakan untuk meningkatkan aktivitas belajar adalah model cooperative learning atau pembelajaran kooperatif [2]. Ada banyak tipe model pembelajaran kooperatif diantaranya CIRC (Cooperative Integrated Reading Composition) dan Model pembelajaran kooperatif tipe lainnya adalah TTW (Think-Talk-Write).

Model pembelajaran kooperatif tipe CIRC (Cooperative Integrated Reading Composition) merupakan merupakan salah satu model yang tepat digunakan dalam proses pembelajaran sehingga menjadi pembelajaran yang bermakna, kontekstual dan tidak membosankan [7]. [8] juga berpendapat bahwa menggunakan model pembelajaran kooperatif tipe CIRC akan menciptakan suatu kegiatan atau susasana yang kooperatif dan komunikatif. Hal ini dikarenakan model pembelajaran kooperatif tipe CIRC menuntut mahasiswa belajar secara berkelompok, lalu guru memberikan materi untuk dipahami mahasiswa, kemudian mahasiswa menyusun kembali pemahaman materi yang sudah didiskusikan dengan kelompoknya yang dituangkan dalam kalimat sendiri [7]. Tidak hanya itu, model pembelajaran kooperatif tipe CIRC juga memiliki tiga prinsip yaitu hubungan aktivitas dasar, keteraturan langsung dalam pemahaman membaca, dan integrasi antara seni bahasa dan menulis [9]. Secara langsung maupun secara tidak langsung, model pembelajaran kooperatif tipe CIRC mampu mengasah aktivitas belajar mahasiswa. Seperti aktivitas pada saat diskusi untuk melakukan kegiatan meramal, bertanya, menulis, merevisi, mengidentifikasi, mengetahui dimana masalahnya dan solusi dari membaca atau artikel serta kegiatan lain seperti meringkas, menambah kosakata, mengeja dan memahami bacaan [9]

Penelitian tentang model pembelajaran kooperatif tipe CIRC telah banyak dilakukan oleh para ahli. Namun, kebanyakan dari penelitian tersebut menggunakan variabel yang sudah biasa seperti kemampuan menulis esai [10], kemampuan membaca [11], meningkatkan pemahaman [12], meningkatkan hasil belajar [13], membangun ide dan gagasan [14], kemampuan membaca [15], serta mengkombinasikan dengan media pembelajaran [16]. Tidak banyak dari peneliti yang menggunakan model pembelajaran kooperatif tipe CIRC pada aktivitas belajar secara umum. Bahkan, tidak banyak peneliti yang membandingkannya dengan model pembelajaran kooperatif lainnya. Oleh karena itu, peneliti akan mencoba meneliti tentang model pembelajaran kooperatif tipe CIRC pada aktivitas belajar mahasiswa.

Model pembelajaran kooperatif tipe lainnya adalah TTW (Think-Talk-Write). Menurut [17] model pembelajaran kooperatif tipe TTW merupakan pembelajaran yang diawali dengan berpikir secara mendalam dengan cara menyimak (think), dikomunikasikan dengan presentasi/ 
diskusi (talk), dan membuat laporan presentasi (write). Model pembelajaran kooperatif tipe TTW bertujuan untuk membangun pemikiran, merefleksi, dan mengorganisasi ide, kemudian menguji ide [18]. Model pembelajaran kooperatif tipe TTW juga dapat menumbuhkan dan mengembangkan keterampilan pemecahan masalah yang kreatif melalui keterlibatan mahasiswa dalam berpikir atau berdialog dengan teman sebayanya lalu menulis inti sari dari percakapan tersebut [19].

Penelitian tentang model pembelajaran kooperatif tipe TTW juga telah banyak dilakukan oleh para ahli. Namun, kebanyakan dari penelitian tersebut juga menggunakan variabel yang sudah biasa seperti kemampuan pemecahan masalah [20], kemampuan disposisi [21], kemampuan menulis [22], kemampuan komunikasi matematik [23], kemampuan menganalisis [24], meningkatkan hasil belajar [25], dan dipadukan dengan media pembelajaran [26]. Akan tetapi, model pembelajaran kooperatif tipe TTW pernah dibandingkan dengan model pembelajaran kooperatif tipe lain. Seperti yang dilakukan oleh [27] yang membandingkan TTW dengan NHT (Numbered Head Together), yang dilakukan oleh [28] yang membandingkan TTW dengan TPS (ThinkPair-Share), dan lainnya. Dan pada kesempatan ini, peneliti akan mencoba membandingkan TTW dengan CIRC.

Dapat disimpulkan bahwa model pembelajaran kooperatif tipe CIRC dan TTW telah banyak diteliti. Akan tetapi, tidak banyak penelitian yang mengkaji dampak model kooperatif ini pada aktivitas belajar mahasiswa. Lalu, model pembelajaran kooperatif yang mempunyai banyak tipe tidak pernah diuji perbandingan untuk mengetahui penggunaan model pembelajaran kooperatif mana yang lebih baik untuk aktivitas belajar mahasiswa. Berdasarkan uraian tersebut, peneliti tertarik untuk melakukan penelitian yang berjudul "Perbandingan Model Pembelajaran Koperatif Tipe CIRC Dan TTW Pada Aktivitas Belajar Mahasiswa". Dengan tujuan untuk mengetahui; apakah ada perbedaan rata-rata aktivitas belajar mahasiswa melalui model pembelajaran kooperatif tipe CIRC, apakah ada perbedaan rata-rata aktivitas belajar mahasiswa melalui model pembelajaran kooperatif tipe TTW, dan apakah ada perbedaan dalam menggunakan model pembelajaran kooperatif tipe CIRC dan TTW pada aktivitas belajar.

\section{METODE PENELITIAN}

Penelitian ini adalah penelitian eksperimen yang menggunakan Completely Randomized Design. Penelitian eksperimen yang menggunakan Completely Randomized Design berarti tidak menggunakan kelas kontrol. Hal ini dikarenakan peneliti menggunakan 2 model pembelajaran yang akan di eksperimen kan. Lalu, peneliti melakukan penelitian komparatif untuk membandingkan kedua model pembelajaran tersebut. Populasi pada penelitian eksperimen ini adalah mahasiswa Universitas Indraprasta yang terdiri dari 2 kelas. Kelas pertama berjumlah 24 orang dan kelas kedua berjumlah 30 orang. Teknik pengumpulan data pada penelitian ini adalah kuesioner yang digunakan untuk mendapatkan hasil aktivitas belajar dan dokumentasi untuk mendapatkan hasil secara langsung (nilai uts dan uas). Semester ganjil 2019-2020 septemberjanuari 2020 sebelum pandemik covid-19.

Tahap pelaksanaan pada penelitian dibagi menjadi 3 bagian yaitu pelaksanaan awal, pelaksanaan inti, dan pelaksanaan akhir. Pada tahap pelaksanaan awal, peneliti membagikan kuesioner kepada mahasiswa untuk mengetahui aktivitas belajar mahasiswa sebelum penggunaan model pembelajaran kooperatif tipe CIRC dan TTW. Pada tahap pelaksanaan inti, peneliti 
menentukan model pembelajaran kooperatif tipe CIRC dan TTW pada dua kelas eksperimen. Kelas Eksperimen 1 menggunakan model pembelajaran kooperatif tipe CIRC dan kelas eksperimen 2 menggunakan model pembelajaran kooperatif tipe TTW. Pelaksanaan model ini dilakukan beberapa kali pada saat pertemuan tatap muka. Pada tahap pelaksanaan akhir, peneliti membagikan kuesioner lagi kepada mahasiswa untuk mengetahui aktivitas belajar setelah penggunaan model pembelajaran kooperatif tipe CIRC dan TTW. Setelah itu, data di analisis dan disimpulkan dengan menggunakan rumus statistik deskriptif dan lainnya.

\section{HASIL DAN PEMBAHASAN}

Data penelitian yang telah didapatkan diolah untuk mengetahui kesimpulan dari penelitian. Pengolahan data diawali dengan mendeskripsikan data penelitian. Hasil penelitian uji deskriptif dapat dilihat pada tabel 1, uji Normalitas dapat dilihat pada tabel 2, uji statistic non parametrik dapat dilihat pada tabel 3, dan Hasil Pengujian Mann-Whitney dapat dilihat pada tabel 4.

Tabel 1. Hasil Uji Deskriptif

\begin{tabular}{lccccc}
\hline & N & Minimum & Maximum & Mean & Std. Deviation \\
\hline Pre Eksperimen CIRC & 24 & 0 & 98 & 61.58 & 26.771 \\
Pre CIRC - Aktivitas Belajar & 24 & 48 & 72 & 57.67 & 6.384 \\
Post Eksperimen CIRC & 24 & 0 & 95 & 65.21 & 27.054 \\
Post CIRC - Aktivitas Belajar & 24 & 68 & 92 & 77.67 & 6.384 \\
Pre Eksperimen TTW & 30 & 0 & 98 & 65.17 & 23.653 \\
Pre TTW - Aktivitas Belajar & 30 & 37 & 72 & 54.67 & 8.899 \\
Post Eksperimen TTW & 30 & 56 & 95 & 74.30 & 10.363 \\
Post TTW - Aktivitas Belajar & 30 & 57 & 92 & 74.67 & 8.899 \\
Valid N (listwise) & 24 & & & & \\
\hline
\end{tabular}

Tabel 2. Hasil Uji Normalitas

\begin{tabular}{lcccccc}
\hline & \multicolumn{3}{c}{ Kolmogorov-Smirnov } & \multicolumn{3}{c}{ Shapiro-Wilk } \\
& Statistic & Df & Sig. & Statistic & Df & Sig. \\
\hline Pre Eksperimen CIRC & .209 & 24 & .008 & .821 & 24 & .001 \\
Pre CIRC - Aktivitas Belajar & .165 & 24 & .089 & .920 & 24 & .057 \\
Post Eksperimen CIRC & .257 & 24 & .000 & .739 & 24 & .000 \\
Post CIRC - Aktivitas Belajar & .165 & 24 & .089 & .920 & 24 & .057 \\
Pre Eksperimen TTW & .203 & 24 & .012 & .807 & 24 & .000 \\
Pre TTW - Aktivitas Belajar & .139 & 24 & .200 & .960 & 24 & .434 \\
Post Eksperimen TTW & .106 & 24 & .200 & .967 & 24 & .599 \\
Post TTW - Aktivitas Belajar & .139 & 24 & .200 & .960 & 24 & .434 \\
\hline
\end{tabular}

Tabel 3. Hasil Uji Statistik Non-Parametrik

\begin{tabular}{ccc} 
& $\begin{array}{c}\text { Post Eksperimen CIRC - Pre } \\
\text { Eksperimen CIRC }\end{array}$ & $\begin{array}{c}\text { Post Eksperimen TTW - Pre } \\
\text { Eksperimen TTW }\end{array}$ \\
\hline $\mathrm{Z}$ & $-1,543$ & $-2,893$ \\
Asymp. Sig. (2-tailed) &, 123 &, 004 \\
\hline
\end{tabular}


Tabel 4. Hasil Pengujian Mann-Whitney

\begin{tabular}{lr}
\hline & Model Pembelajaran - Aktivitas Belajar \\
\hline Mann-Whitney U & 318.500 \\
Wilcoxon W & 618.500 \\
Z & -.724 \\
Asymp. Sig. (2-tailed) & .469 \\
\hline
\end{tabular}

Dari tabel 1 diketahui jumlah sampel di kelas eksperimen 1 sebanyak 24 orang dan di kelas eksperimen 2 sebanyak 30 orang. Nilai minimum untuk pre dan post eksperimen CIRC sebesar 0, sedangkan pre eksperimen TTW sebesar 0 dan post eksperimen TTW sebesar 56. Nilai maximum untuk pre dan post eksperimen CIRC dan TTW sebesar 98 dan 95. Nilai mean pre eksperimen CIRC sebesar 61,58 dan TTW sebesar 65,17 , nilai mean post eksperimen CIRC sebesar 65,21 dan TTW sebesar 74,30. Nilai standar deviasi pre eksperimen CI sebesar 26,771 dan TTW sebesar 23,653, nilai standar deviasi post eksperimen CIRC sebesar 27,054 dan TTW sebesar 10,363. Selanjutnya dilakukan uji normalitas data untuk mengetahui apakah data penelitian bersifat normal atau tidak normal. Uji normalitas data pada penelitian eksperimen ini menggunakan uji Kolmogorov-Smirnov dan uji Shapiro-Wilk. Hasil tabel 2 menunjukkan hasil dari uji KolmogorovSmirnov dan uji Shapiro-Wilk. Dari pre dan post kelas eksperimen dan aktivitas belajar diketahui bahwa 5 dari 8 item yang terdistribusi normal sedangkan 3 lainnya tidak terdistribusi normal. Jadi, dapat dikatakan bahwa data tidak terdistribusi dengan normal. Ketika data tidak terdistribusi secara normal maka dilakukan pengujian statistik non parametrik dengan uji wilcoxon. Berdasarkan hasil uji wilcoxon pada tabel 3 untuk model pembelajaran kooperatif tipe CIRC menunjukkan nilai asymp. sig. sebesar $0.123>0,050$ yang artinya tidak ada perbedaan rata-rata pada aktivitas belajar mahasiswa melalui model pembelajaran kooperatif tipe CIRC. Untuk model pembelajaran kooperatif tipe TTW menunjukkan nilai asymp. sig. sebesar $0.004<0,050$ yang artinya ada perbedaan rata-rata pada aktivitas belajar mahasiswa melalui model pembelajaran kooperatif tipe TTW. Pengujian selanjutnya digunakan untuk mengetahui apakah ada perbandingan penggunaan model pembelajaran kooperatif tipe CIRC dan TTW pada aktivitas belajar. Pengujian statistic non parametrik ini menggunakan uji mann-whitney. Pengambilan keputusan pada uji mannwhitney dengan cara membandingkan nilai asymp. sig. Apabila nilai asymp. sig. $>0.050$ maka tidak ada perbedaan penggunaan model pembelajaran kooperatif tipe CIRC dan TTW pada aktivitas belajar dan sebaliknya. Hasil uji mann-whitney pada tabel 4 menunjukkan bahwa nilai asymp. sig. sebesar $0.469>$ 0,050 , yang artinya tidak ada perbedaan dalam menggunakan model pembelajaran kooperatif tipe CIRC dan TTW pada aktivitas belajar.

\section{Pembahasan}

1. Model pembelajaran Kooperatif tipe CIRC pada aktivitas belajar mahasiswa

Hasil penelitian menunjukkan bahwa tidak ada perbedaan rata-rata aktivitas belajar mahasiswa dengan menggunakan model pembelajaran kooperatif tipe CIRC. Hasil ini berlawanan dengan penelitian yang diungkapkan oleh [29] bahwa model pembelajaran kooperatif tipe CIRC dapat meningkatkan aktivitas. 
Berdasarkan temuan dilapangan, tidak adanya perbedaan aktivitas belajar sebelum dan sesudah diterapkan model pembelajaran kooperatif tipe CIRC dikarenakan beberapa alasan. Pertama, perbedaan nilai pre dan post yang tidak terlalu jauh menandakan ketidakcocokan antra model pembelajaran dengan kelas yang dipakai. Kedua, perbedaan aktivitas belajar sebelum dan sesudah penggunaan model pembelajaran kooperatif tipe CIRC tidak terlihat (contoh: siswa yang pasif tetap pasif ketika model pembelajaran kooperatif tipe CIRC diterapkan). Menurut [30], tidak adanya perbedaan rata-rata aktivitas belajar saat penggunaan model pembelajaran kooperatif tipe CIRC dikarenakan dampak yang dirasakan mahasiswa hanya tertarik pada hal tertentu. Maksudnya, sebagian mahasiswa ada yang mampu beradaptasi dengan model pembelajaran ini dan sebagiannya lagi tidak mampu beradaptasi. Mampu atau tidaknya beradaptasi dengan model pembelajaran ini disebabkan oleh gaya belajar yang dimiliki oleh mereka [31]. Pada kasus penggunaan model pembelajaran kooperatif tipe CIRC, mahasiswa dituntut untuk membaca. Sedangkan, tidak semua mahasiswa menyukai gaya belajar membaca. Oleh sebab itu, hal ini tidak dapat menunjukkan reaksi perubahan sebelum dan sesudah penggunaan model pembelajaran kooperatif tipe CIRC. Pada pelaksanaan eksperimen model pembelajaran kooperatif tipe CIRC. Pada saat pre eksperimen, nilai terendah adalah 0 dan nilai tertinggi adalah 98 dengan nilai rata-rata sebesar 61,58. Pada saat post eksperimen, nilai terendah adalah 0 dan nilai tertinggi adalah 95 dengan nilai rata-rata sebesar 65,21.
Perbandingan rata-rata secara keseluruhan antara pre dan post hanya meningkat sebesar 3,63.

2. Model pembelajaran kooperatif tipe TTW pada aktivitas belajar mahasiswa

Hasil penelitian menunjukkan bahwa ada perbedaan rata-rata aktivitas belajar mahasiswa dengan menggunakan model pembelajaran kooperatif tipe TTW. Hasil penelitian ini sejalan dengan hasil penelitian yang dilakukan oleh [32] yang mengatakan bahwa model pembelajaran kooperatif tipe TTW dapat meningkatkan aktivitas dan hasil belajar kognitif. Hasil penelitian ini juga sejalan dengan penelitian yang dilakukan oleh [33] yang menjelaskan bahwa model pembelajaran kooperatif tipe TTW dapat meningkatkan aktivitas belajar dan kemampuan menulis. Artinya, model pembelajaran kooperatif tipe TTW benar-benar dapat berpengaruh pada aktivitas belajar mahasiswa. Menurut [34], adanya perbedaan ratarata aktivitas belajar pada penggunaan model pembelajaran kooperatif tipe TTW dikarenakan model ini mempunyai peran penting yang dapat men-stimulus mahasiswa untuk terlibat secara aktif dalam kegiatan pembelajaran secara tidak langsung dan model ini dapat beradaptasi baik dengan aktivitas belajar (seperti berpikir, berbicara, dan menulis) yang memberikan peluang kepada mahasiswa untuk berpartisipasi aktif [35]. Hubungan model pembelajaran kooperatif tipe TTW dan aktivitas belajar dapat digambarkan apabila semakin tinggi analisisnya, aktivitas belajar yang dilakukan mahasiswa dan penguasaan materi setiap mahasiswa maka semakin tinggi pula tingkat 
keberhasilan pembelajaran [24]. Pada pelaksanaan eksperimen model pembelajaran kooperatif tipe TTW. Pada saat pre eksperimen, nilai terendah adalah 0 dan nilai tertinggi adalah 98 dengan nilai rata-rata sebesar 65,17. Pada saat post eksperimen, nilai terendah adalah 56 dan nilai tertinggi adalah 95 dengan nilai rata-rata sebesar 74,3. Perbandingan rata-rata secara keseluruhan antara pre dan post hanya meningkat sebesar 9,13.

3. Perbandingan Model pembelajaran Kooperatif tipe CIRC dan TTW pada aktivitas belajar mahasiswa Hasil penelitian menunjukkan bahwa tidak ada perbedaan aktivitas belajar dalam menggunakan model pembelajaran kooperatif tipe CIRC dan TTW pada aktivitas belajar mahasiswa. Tidak adanya perbedaan aktivitas belajar dari penggunaan model CIRC dan TTW dikarenakan beberapa faktor. Pertama, perbedaan nilai mahasiswa sebelum dan sesudah penggunaan model pembelajaran kooperatif tipe CIRC dan TTW. Kedua, perbedaan nilai aktivas belajar mahasiswa sebelum dan sesudah penggunaan model pembelajaran kooperatif tipe CIRC dan TTW. Ketiga, jumlah mahasiswa dikelas ekspermien 1 dan kelas eksperimen 2. Keempat, perbedaan akademik mahasiswa setiap kelas. Kelima, situasi dan kondisi pada saat pelaksanaan model pembelajaran kooperatif tipe CIRC dan TTW. Berdasarkan beberapa faktor tersebut dapat disimpulkan bahwa model pembelajaran kooperatif tipe CIRC dan TTW dapat berpengaruh terhadap aktivitas belajar secara sama (tanpa adanya perbedaan). Perbandingan pada saat pelaksanaan eksperimen model pembelajaran kooperatif tipe
CIRC dan TTW. Pada saat pre eksperimen, nilai terendah model pembelajaran kooperatif tipe CIRC dan TTW adalah 0 dan nilai tertinggi model pembelajaran kooperatif tipe CIRC dan TTW adalah 98, dengan nilai rata-rata sebesar 61,58 dan 65,17 . Perbandingan nilai pre antara model pembelajaran kooperatif tipe CIRC dan TTW adalah 3,59, yang didominasi oleh model pembelajaran kooperatif tipe TTW. Pada saat post eksperimen, nilai terendah model pembelajaran kooperatif tipe CIRC adalah 0 dan TTW adalah 56, sedangkan nilai tertinggi model pembelajaran kooperatif tipe CIRC dan TTW adalah 95, dengan nilai rata-rata sebesar 65,21 dan 74,3. Perbandingan nilai post antara model pembelajaran kooperatif tipe CIRC dan TTW adalah 9,09, yang didominasi oleh model pembelajaran kooperatif tipe TTW.

\section{SIMPULAN}

Berdasarkan hasil dan pembahasan yang telah disampaikan maka dapat disimpulkan sebagai berikut.

1. Tidak ada perbedaan rata-rata aktivitas belajar dengan menggunakan model pembelajaran kooperatif tipe CIRC.

2. Ada perbedaan rata-rata aktivitas belajar dengan menggunakan model pembelajaran kooperatif tipe CIRC.

3. Tidak ada perbedaan dalam menggunakan model pembelajaran kooperatif tipe CIRC dan TTW pada aktivitas belajar.

\section{DAFTAR PUSTAKA}

[1] R. Vhalery, "Perbandingan Model Pembelajaran Kooperatif Tipe Gallery walk dengan Tipe Learning together pada Aktivitas Belajar Peserta Didik di SMA Tri Dharma Palembang," 2019. 
[2] L. Mufidah, D. Effendi, and T. T. Purwanti, "Penerapan Model Pembelajaran Kooperatif Tipe Tps Untuk Meningkatkan Aktivitas Belajar Siswa Pada Pokok Bahasan Matriks," J. Pendidik. Mat. STKIP PGRI Sidoarjo, vol. 1, no. 1, pp. 117-125, 2013.

[3] D. A. Nurmala, L. E. Tripalupi, and N. Suharsono, "Pengaruh Motivasi Belajar Dan Aktivitas Belajar Terhadap Hasil Belajar Akuntansi," J. Pendidik. Ekon., vol. 4, no. 1, pp. 86-95, 2014.

[4] R. Vhalery, "Perbandingan Aktivitas Belajar Melalui Model Pembelajaran Kooperatif Tipe Group Investigation Dan Numbered Head Together," Res. Dev. J. Educ., vol. 6, no. 1, pp. 8093, 2019.

[5] Hasriyanti and A. N. C. Ramadhani, "The Influence of the Learning Model Cooperative Integrated Reading and Composition ( CIRC ) on The Learning Outcomes of High School Students," J. LA Geogr., vol. 18, no. 1, 2019.

[6] I. K. Suparya, "Pengaruh Model Pembelajaran Kooperatif Tipe Think Talk Write (TTW) Terhadap Hasil Belajar Dan Kemampuan Berpikir Kritis Pada Pembelajaran Ipa Di Sekolah Dasar," Widyacarya, vol. 2, no. 2, pp. 1924, 2018.

[7] S. Karimah, "Pembelajaran Matematika Model Cooperative Integrated Reading And Composition (CIRC) Untuk Meningkatkan Kemampuan Komunikasi Matematis Materi Segiempat Kelas VII," Delta J. Ilm. Pendidik. Mat., vol. 1, no. 2, pp. 136-143, 2017.

[8] I. I. Pratita, "Pengembangan Model Cooperative Integrated
Reading And Composition (CIRC) Untuk Meningkatkan Kemampuan Membaca Pemahaman (Dokkai) Mahasiswa Jurusan Bahasa Dan Sastra Jepang Universitas Negeri Surabaya," J. ASA, vol. 4, 2017.

[9] R. H. Ristanto, S. Zubaidah, M. Amin, and F. Rohman, "The Potential of Cooperative Integrated Reading and Composition in Biology Learning at Higher Education," Int. J. Educ. Res. Rev., vol. 3, no. 2, pp. 50-56, 2018, doi: 10.24331/ijere.376727.

[10] O. Mustyka, "Peningkatan Keterampilan Menulis Esaimelalui Model Cooperative Integrated Reading And Composition (CIRC)," J. Pendidik. Rokania, vol. 1, no. 2, pp. 9-18, 2016.

[11] E. Durukan, "Effects of cooperative integrated reading and composition (CIRC) technique on reading-writing skills," Educ. Res. Rev., vol. 6, no. 1, pp. 102-109, 2011.

[12] M. Khoroid, D. Trapsilasiwi, and S. Setiawani, "Penerapan Pembelajaran Kooperatif Tipe CIRC (Cooperative Integration Of Reading And Composition) Untuk Eningkatkan Hasil Belajar Siswa Pada Pokok Bahasan Irisan Dan Gabungan Dua Himpunan Kelas VII A Smp 1 Islam jember Semester Genap Tahun Pelajaran 2012/2," J. Kadikma, vol. 4, no. 3, 2013.

[13] S. Arbi, "Upaya Peningkatan Hasil Belajar Ipa Melalui Penerapan Model Cooperative Learning Tipe Circ Siswa Kelas Viii 2 Semester Ii Smpn 1 Bukit Batu Ta 2014/2015," Prim. J. Pendidik. Guru Sekol. Dasar, vol. 4, no. 2, p. 187, 2015, doi: 10.33578/jpfkip.v4i2.2952.

[14] A. P. N. Ali and M. Mustadjar, 
"Pengaruh Model Pembelajaran Cooperative Integrated Reading Composition (CIRC) Dalam Meningkatkan Hasil Belajar Sosiologi Siswa Kelas Xi Ips 1 Di SMA Negeri 2 Bantaeng," J. Sos. Pendidik. sosiologi-FIS UNM, pp. 7-13, 2016.

[15] E. Sulistianingsih, "Developing Students' Participation in a Mixedlevels Reading Class via Cooperative Integrated Reading and Composition (CIRC)," Vis. J. Lang. Foreign Lang. Learn., vol. 7, no. 1, p. 1, 2018, doi: 10.21580/vjv7i12200.

[16] S. Marpuah, M. Rahayuningsih, and S. Sukaesih, "Efektivitas Model Pembelajaran Cooperative Integrated Reading and Composition (Circ) Dengan Mind Mapping," J. Biol. Educ., vol. 4, no. 3, pp. 244-250, 2015.

[17] A. S. Susanto, H. Bharata, and S. Dahlan, "The effect of Cooperative Learning Model Think-Talk-Write Type on Mathematical Problem-Solving Abilities In Terms of Learning Habits," Al-Jabar J. Pendidik. Mat., vol. 9, no. 1, 2018, doi: 10.24042/ajpm.v9i1.2235.

[18] L. A. Sumirat, "Efektifitas Strategi Pembelajaran Kooperatif Tipe Think-Talk-Write

(TTW)

Terhadap Kemampuan Komunikasi Dan Disposisi Matematis Siswa," J. Pendidik. dan Kegur., vol. 1, no. 2, 2014.

[19] S. Huda, Munifah, and R. Umam, "Think Talk Write ( TTW ) learning strategy and effects on creative problem-solving skills and creativity," J. Gift. Educ. Creat., vol. 7, no. 1, pp. 25-32, 2020.

[20] A. D. N. Afriyani, M. Chotim, and I. Hidayah, "Keefektifan
Pembelajaran Ttw Dan Sgw Berbantuan Kartu Soal Terhadap Kemampuan Pemecahan Masalah," Unnes J. Math. Educ., vol. 3, no. 1, 2014.

[21] Guswinda, P. Yuanita, and N. M. Hutapea, "Improvement of Mathematical Problem Solving and Disposition Ability of MTs Students through StrategiesThink Talk Write in Cooperative Learning in Kuantan Singingi Regency," J. Educ. Sci., vol. 3, no. 3, 2020.

[22] Anisah, M. Asikin, and I. Hidayah, "Mathematical writing ability through Cooperative Learning with Think Talk Write ( TTW )," Unnes J. Math. Educ., vol. 9, no. 1, pp. 28-36, 2020, doi: 10.15294/ujme.v9i1.38097.

[23] N. Elida, "Meningkatkan Kemampuan Komunikasi Matematik Siswa Sekolah Menengah Pertama Melalui Pembelajaran Think-Talk-Write (TTW)," Infin. J., vol. 1, no. 2, p. 178, 2012.

[24] E. N. Sari and E. Setiawati, "Kemampuan Siswa Dalam Menganalisis Materi Sejarah Dengan Menggunakan Model Cooperative Learning Tipe Think Talk Write (TTW) Di Sma Negeri 1 Pekalongan," J. Chem. Inf. Model., vol. 53, no. 9, pp. 16891699, 2019.

[25] L. Mawartiningsih and U. Sholikah, "The Application Of Cooperative Learning Model Think Talk Write (TTW) Type On Ecosystems To Increase Learning Result Of Junior High School Students," EDUSAINS, vol. 10, no. 1, pp. 120-126, 2018.

[26] M. Sariningrum, I. Mahardika, and B. Supriadi, "Pembelajaran Kooperatif Tipe TTW (Think Talk 
Write) Disertai Lks Berbasis Multirepresentasi Dalam Pembelajaran Fisika Di SMA," $J$. Pembelajaran Fis., vol. 5, no. 4, 2017.

[27] L. F. Sufi, H. Bharata, and R. Asnawati, "Perbandingan Pemahaman Konsep Matematis Antara Model Pembelajaran Kooperatif Tipe Ttw Dan Nht," J. Pendidik. Mat. Unila, vol. 3, no. 2, 2015.

[28] A. P. Kusuma, Budiyono, and D. R. S. Saputro, "Eksperimentasi Model Pembelajaran TTW Dan TPS Pada Materi Bangun Ruang Sisi Datar Ditinjau Dari Kemampuan Penalaran Matematis Siswa," J. Elektron. Pembelajaran Mat., vol. 3, no. 2, pp. 190-203, 2015.

[29] Ya'syahibal, Hairida, and H. . Melati, "Peningkatan Aktivitas Dan Hasil Belajar Siswa Melalui Model Cooperative Integrated Reading And Composition (CIRC)," 2013.

[30] M. H. Irawadi, I. N. Martha, and I. W. Wendra, "Penerapan Model Pembelajaran Integrated Reading and Composition (CIRC) untuk Meningkatkan Hasil Belajar Siswa dalam Menulis Karya Ilmiah di Kelas XII AP I SMK Negeri 1 Seririt," J. Pendidik. Bhs. dan Sastra Indones., vol. 3, no. 1, pp. $1-11,2015$.
[31] R. Vhalery, D. Hartono, and A. W. Leksono, "Kontribusi Gaya Belajar Pada Aktivitas Belajar Matematika Ekonomi," $J$. Pendidik. Ekon., vol. 12, no. 2, pp. 78-86, 2019, doi: 10.17977/UM014v12i22019p78.

[32] L. Naimnule, V. Oetpah, and V. U. R. Sila, "Peningkatan Aktivitas Dan Hasil Belajar Kognitif Siswa Melalui Penerapan Model Pembelajaran Think Talk Write (TTW) Di SMUK," J. Pendidik., vol. 1, no. 10, pp. 2050-2053, 2016.

[33] I. W. Kerti, "Penerapan Srtategi Pembelajaran Think Talk Write (Ttw) Bermedia Gambar Untuk Meningkatkan Aktivitas Belajar Dan Keterampilan Menulis Puisi Siswa," Cetta J. Ilmu Pendidik., vol. 1, no. 2, 2018.

[34] A. Yazid, "Pengembangan Perangkat Pembelajaran Matematika Model Kooperatif Dengan Strategi Ttw (Think- TalkWrite) Pada Materi Volume Bangun Ruang Sisi Datar," J. Prim. Educ., vol. 1, no. 1, 2012.

[35] L. Listiana, "Pemberdayaan Keterampilan Berpikir Dalam Pembelajaran Biologi Melalui Model Kooperatif Tipe GI (Group Investigation) Dan TTW (Think, Talk, Write)," in Proceeding Biology Education Conference: Biology, Science, Enviromental, and Learning, 2013, no. 1. 